\title{
Comparative Analysis on the Impact of Chinese and Western Trade and Investments in Africa
}

\author{
Mirana Annicet Rasoanomenjanahary \\ School of Business Administration, Zhongnan University of Economics and Law, Wuhan, China \\ Email:miranaannicet@yahoo.com
}

How to cite this paper: Rasoanomenjanahary, M. A. (2021). Comparative Analysis on the Impact of Chinese and Western Trade and Investments in Africa. American Journal of Industrial and Business Management, 11, 1198-1217.

https://doi.org/10.4236/ajibm.2021.1112072

Received: November 6, 2021

Accepted: December 10, 2021

Published: December 13, 2021

Copyright (c) 2021 by author(s) and Scientific Research Publishing Inc. This work is licensed under the Creative Commons Attribution International License (CC BY 4.0).

http://creativecommons.org/licenses/by/4.0/

\begin{abstract}
In this article, we examine Chinese, western trade, and foreign direct investment in Africa, which Chinese part has grown significantly in the previous decade, and investigate the structure and size of China, the West in terms of trade and foreign direct investment (FDI) to Africa operations. We first analyze the current situation of China and western countries' trade and FDI in African nations by highlighting the importance of Chinese trade and FDI compared to the West, an old continent partner. This research looks at how Africa might take advantage of the untapped potential presented by China's growing investment and trade relations and how with the other continent. By utilizing the latest research and data on this subject, this paper endeavors to analyze China's growing importance in Africa's growth and development, comparing and contrasting their successes through win-win strategies compared dominance strategies to those in Western countries.
\end{abstract}

\section{Keywords}

Western Countries, China, Investments, Trade, Africa, Relationships, Comparative Analysis, Belt and Road

\section{Introduction}

Since the opening of the Chinese market in the 1970s, China has become an important trading partner country to most of the developed and developing economies. Thanks to its technological innovation, the increasing of imports and exports, cheap labor, private business, and market incentives development, mainly thanks to China's machinery industry China, has achieved double-digit growth (Xinhua, 2021), which places it among the giants of the world economy. After overtaking France and United Kingdom in 2005, then Germany in 2007, China ranked second in the world in terms of Research and Development in 2003, with 
a growth rate of $9.3 \%$. The Chinese economy gained the upper hand over Japan in 2010, with Gross Domestic Product (GDP) reaching nearly \$5.9 trillion, which is $7 \%$ more than the GDP of Japan, but 2.5 times less than the US GDP, which amounted to over this period to 14.660 billion dollars. Thus, the Chinese economy grows three times faster from $10 \%$ to $12 \%$ on an annual average against 3\% to $4 \%$. Hence, in 2014 China dethroned the United States and became the world's largest economy. According to the IMF, its GDP represents $16.5 \%$ of global wealth, against $16.3 \%$ for Americans. China's economy is the world's largest exporter. China exported \$2.41 trillion and imported \$1.54 trillion in 2017, resulting in an $\$ 873$ billion trade surplus. In the year 2020, China was the world's number two economy in terms of GDP, number one in total export, and number two in terms of import according to Economic Complexity Index (ECI).

Furthermore, the economies of most African countries are highly trade-dependent. It is unavoidable that they will be susceptible to a wide range of external shocks, such as global oil prices, foreign income, and monetary policy shocks, particularly from trade partners, and internal shocks, such as political instability and insecurity. To what extent has China, France, the US, Germany, the United Kingdom, and others affected Africa's economies has been a critical source of worry for investors, trade relations, policymakers, and academics.

This study diverges from previous research by focusing on how old partners (Western nations) face China's investment and trade evolution in Africa.

China's trade with Africa is growing at a similar rate as its trade with the rest of the globe, but slower. According to Xu (2008), trade between China and Africa peaked in 1990 at US $\$ 935$ million, then grew to US $\$ 10.6$ billion in 2000 and US $\$ 55.5$ billion in 2006. Africa's exports to China increased by more than $40 \%$ annually from 2001 to 2006, reaching US $\$ 28.8$ billion, while Africa's purchases from China tripled to US\$26.7 billion (Wang, 2007). After the United States and France, China was Africa's third-largest trading partner, according to Ajakaiye (2006). While the expansion of trade and investment between Africa and China has been generally welcomed.

Otherwise, foreign direct investments in Africa have been traditionally from the West (Nnajiofor, 2019). African countries have a propensity toward embracing Western enterprises and businesses. It observed that, compared to firms from other areas of the world, the bulk of Western enterprises founded on the continent are from the West. Still, this propensity since the age of independence has not produced satisfying outcomes for some African countries. For this reason, by employing a win-win strategy, the Chinese are now viewed as a viable alternative.

\subsection{Study Objective, Contribution, and Limitation}

The study's primary objective would be to examine the influence of China, Western trade, and FDI on Africa's economic growth and development while also controlling the mediating function of each nation involved in Africa, partic- 
ularly China, the European Union, and the United States.

This research contributes to the body of knowledge in several ways. First, it contributes to a growing body of knowledge about the economic effects of Chinese and Western economic engagements in Africa, particularly in terms of FDI and trade. Second, we demonstrate how China's newcomers in the African market can develop and introduce a commercially successful by considering unique aspects of the Chinese business environment. As well as evaluating how Chinese trade and investment would affect the development and growth in Africa and studying its influence on the relationships between Africa Western which was the traditional partner (Nnajiofor, 2019). Our study adds to this body of knowledge by establishing that Chinese and possibly other countries' investments and trade in African countries are dependent on the host country's leading economic development factor. As a result, the effects of FDI will naturally differ between countries.

This study will fill in the gaps done by previous research, which lacked a horizontally comparative analysis of China's growing economic power in Africa from the perspectives of FDI and trade. Meanwhile, It also fills gaps in the literature that lacks analyzing the different advantages that African countries gain from the Chinese and western countries through trade partnership and FDI. Furthermore, the paper will look at the scope of analysis for two western countries, the U.S and the U.E, to see if the claim that some countries portray a biased and negative image of China's trade and investment engagements in Africa is justified. In terms of theory application, on the one hand, this research will connect the concept of power relations, which has fueled Africa's development in various contexts. China's investment in Africa is increasing, so the findings focus on comparative analysis to see the differences between Chinese and Western investment in Africa and the different aspects on the impacts of the Africa-Chinese relationship. A comparison of the relationship between the Chinese and countries from other continents will also be analyzed to see how are they fare generally.

The main limitation implies that the majority of the literature reviewed and discussed in this study is based on peer-reviewed article comments, media reports, and working papers, which are frequently accepted for publication to reflect the benefit of hindsight in the case of FDI and trade. Given the abundance of empirical research, literature analyzes its impact on development economics and economic growth.

\subsection{Methodology}

The literature for this conceptual research was gathered from various peer-reviewed publications and media outlets, emphasizing a comparative analysis of the influence of FDI and trade on African economic development. Based on the conceptual evaluation, the study has highlighted the uncertainties surrounding important goals of past events to provide some critical insights focusing on a comparative analysis of FDI and trade from China and western countries, which are 
considered sources of economic development in Africa.

A thorough review of the most recent publications collected from academic journals, relevant online news portals, and online platforms yields much more current state-of-the-art knowledge. This approach allowed for a better understanding of current concerns and, as a result, the portrayal of some important policies relating to FDI and trade in Africa.

Otherwise, this article's main quantitative data for monitoring investments were obtained from MOFCOM, UN-Comtrade, Eurostat, World Bank, and UNCTAD. The Chinese Investment Tracker AEI and the Johns Hopkins School of Advanced International Studies Research Initiative provide the rest of the quantitative data. This study's strengths, weaknesses, opportunities, and threats were investigated using a quantitative approach.

The remainder organizes this research as follows: the second section presents the theoretical and empirical literature review. The third section discusses the style facts of Sino-African economic relations. Section fourth focuses on the comparative Analyses of western and China Strategies in Africa, which outline the potential trade and investment advantage between China-Africa and Western-Africa. Describe the comparison between U.S, U.E., and Chinese FDI stock in Africa, summarize the main investing countries of China and the western countries in Africa and finally show the comparable situation of China and the Belt Road initiative. The last section presents the conclusions and recommendations of this study.

\section{Theoretical and Empirical Literature Review}

The concepts behind the benefits of trade between China, Western Europe, and Africa span from the classical comparative cost advantage (Ricardo, 1891) to a neoclassical production factors abundance model (Heckscher and Ohlin, 1991). As classical trade theory dictates, every nation should focus on manufacturing items for which it has lower overall, comparative cost advantages, autarky, pricing, or opportunity costs, and that "nature's particular powers distribute labor in the most effective and economical ways" (Ricardo, 1955). According to neoclassical trade theory, a nation with a much more workforce specializing in labor-intensive manufactured commodities exported in exchange for capital-intensive products is insufficient to anticipate developed-African deals (Eisenman, 2012; Miao et al., 2020). Briefly expressed, these views contend that Africa possesses the rich natural resources developed countries want for economic progress. In contrast, the developed nation has the finance and technological resources that Africa requires to grow. The effects of trade and FDI between Developed countries and Africa remain an essential topic in empirical research.

\subsection{FDI and Economic}

This section has emphasized the connection between FDI and growth. Dunning created the OLI paradigm by merging the Heckscher-Ohlin $(\mathrm{H}-\mathrm{O})$ trade model 
with the internationalization theory to comprehend the objectives of 1960s investors, who managed global industrial chains. The OLI paradigm divided into three sub-paradigms that may use to examine why companies participate in foreign direct investment: ownership (O), location (L), and internalization (I). Three types of determinants are resource-seeking, market-seeking, and efficiency-seeking (Dunning, 2000). Besides, Helpman et al. (2004) fostered the hypothesis connecting foreign direct investment and global exchange.

Foreign direct investment (FDI) is a powerful instrument in the fast-expanding globalization and state-to-state connections. FDI may be an essential tool for local company growth if policies are in place to encourage it. It might also boost the competitiveness of both the receiving and investing economies. The effect of FDI on the host country's economy depends on economic openness, financial and mechanical conditions, human resources, political stability, and viciousness deficit. A significant influence of FDI on growth in emerging nations determine by the host nation and industry characteristics. It also allows the host economy to broaden its product offerings in overseas markets. For a broad spectrum of host and home economies, investment is a critical source of revenue; moreover, it positively impacts the expansion of international trade.

\subsection{Trade and Economic}

The connection between trade and economic growth is one of the most widespread significant theoretical and empirical topics in research. Because of the continuous and substantial changes in economic efficiency across various nations, notably by many emerging countries, expanding global trade integration, the link between economic growth and international commerce has gained considerable interest in recent years (Silajdzic and Mehic, 2018).

The absolute and comparative advantage principles of the classical school of thought, as well as the Heckscher-Ohlin (H-O) assets enrichment trade model, which bases exchange among countries on differences in asset wealth, provide the necessary foundation for the hypothetical link between global business and financial development.

According to Smith's principle of absolute advantage, the benefits of international trade and specialization boosts when one nation has a flat-out cost advantage (Produces a unit of a commodity with less effort). In the other entity, the other country has a total cost-benefit. As per Ricardo's comparative advantage theory, even if a country does not accept a comprehensive cost-benefit in manufacturing both commodities, a wellspring of reciprocal commerce may still exist. The moderately ineffective country should specialize in export the good or services relatively less unproductive. In contrast, the rather productive country should specialize in and generally ship goods more effectively (Krugman et al., 2012).

Furthermore, proponents of the export-led approach and free trade argue that some developing nations who utilized internal-oriented tactics as part of the import-substitution strategy (ISS) experienced bad economic situations (Balassa, 
1978). The export-led growth concept emphasizes the impact of commerce, mainly export, on economic growth. It predicts improved capacity utilization, enhanced economies of scale, and increased technology use. Export development primarily stimulates investment in areas where a country has a competitive edge, boosting national efficiency and increasing the economy. Moreover, Grossman and Helpman (1991) show in their theoretical frameworks that cross-national commerce may assist countries in enhancing their productivity by facilitating the transfer of innovative technology. Interaction among nations may significantly influence the economic efficiency of trade nations via channels such as technological transfers, comparative advantage, and economics of scale. It has a direct influence on capital accumulation, in addition to that. As a result, they enable the transmission of information and technology by importing high-tech products that can promote economic growth.

\section{Style Fact of Sino-African Economic Relations}

The economic link between China and Africa has only stronger since 2000, but the political relationship between the two countries stretches back decades. In reality, China reclaimed its seat in the United States in 1971 thanks to a decisive vote of an African nation who cut diplomatic ties with Taiwan for the benefit of China. Since the 1980s and 1990s, Sino-African connections remained primarily political, while China conducted massive economic reforms and opened up its economy to the rest of the globe.

China's extraordinary development record in the late 1990s convinced authorities that the nation needed to guarantee its future supply of natural resources to continue high levels of growth. In this sense, Africa has become an important destination for China. In response to China's rising interest in Africa, the Forum on China-Africa Cooperation (FOCAC) was established in 2000. The forum has ministerial conferences every three years, providing a significant venue for accomplishing specific economic policy objectives with Africa. Furthermore, China's "Going-Global" initiative, launched in 2001, has supported the expansion of Sino-African trade links. For encouraging the FDI and international trade, the plan gives Chinese businesses easy access to loans, foreign exchange, and other resources, and tax, import, and export regulations favorable to them (UNCTAD and UNDP, 2007). Although the strategy is explicitly not aimed towards Africa, it highlights significant areas where FDI should be promoted, such as resource exploration projects, which account for a substantial portion of China's participation on the continent. Three avenues of interaction stand out for Sino-African economic ties: commerce, assistance (economic cooperation), and FDI (Miao et al., 2020).

\subsection{Trade}

While bilateral trade between China and Africa was negligible before 2000, it has grown substantially in the previous decade, reaching $\$ 166$ billion in 2012 (Figure 1). African exports to China (7.8 percent of GDP) surpassed Chinese 


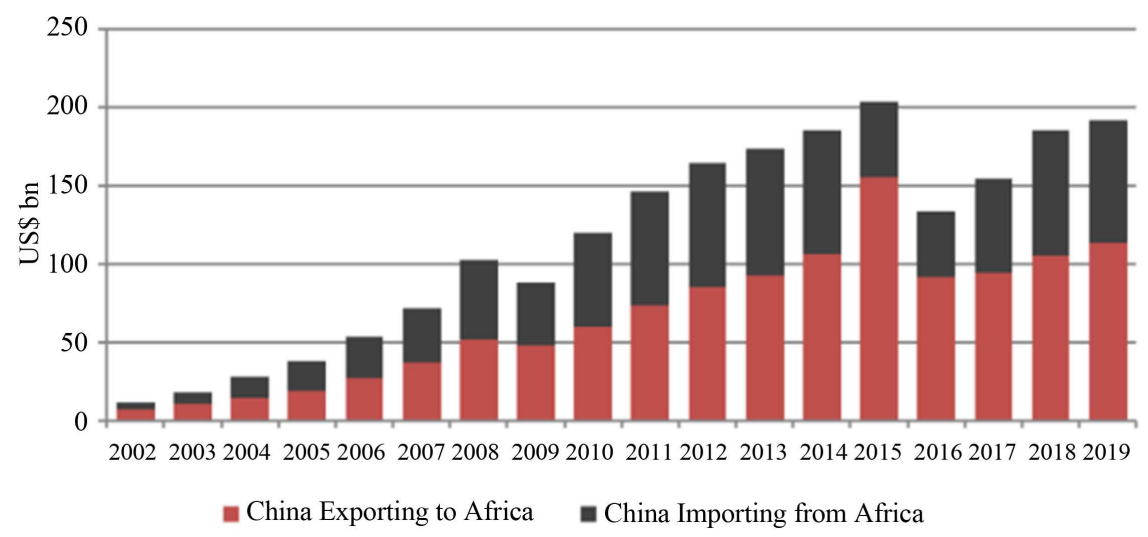

Figure 1. China-Africa trade. Source: U.N. Comtrade.

imports in 2012 (4.8 percent). In monetary terms, this equates to a $\$ 39$ billion total trade surplus. In 2019, China-Africa trade reached $\$ 192$ billion.

The commerce value between China and Africa grew in 2019 to $\$ 192$ billion, up from $\$ 185$ billion in 2018. Angola, Democratic Republic of the Congo, and South Africa, were the leading African exporters to China in 2019. In 2019, the top three purchasers of Chinese commodities were Nigeria, South Africa, and Egypt.

\subsection{FDI}

High-quality China-Africa investment based on win-win, China investment scattered in almost all activity sectors in Africa.

A Chinese company's investments in Africa's infrastructure, manufacturing, and agricultural processing, among other things, have assisted host nations in accumulating foreign currency reserves, promoting technological transfers, and eliminating supply bottlenecks. The investment of Chinese companies in Africa is conducive to strengthening global supply chains. Chinese companies have contributed to African countries' social stability and economic prosperity by carrying out technology transfers, supporting local procurement, and creating good-paying jobs.

Across the continent, most Chinese investments centered on the transportation and energy industries (Figure 2). As previously reported, Nigeria's railway infrastructure has seen substantial Chinese investment. Kenya, Ethiopia, and Zambia are among the nations where the government built the railways. The Chinese Export-Import Bank-funded 85 percent of the $\$ 475$ million Addis Abeba Light Rail, which serves the city's 4 million people. Although oil and gas investments accounted for most energy investments, they also included renewable energy projects such as hydropower.

\subsection{Advantage of China Africa Trade and Investment Relation}

Most scholars say that China-Africa trade has the potential for considerable continued growth. China's investments and Trade in Africa have boosted local 


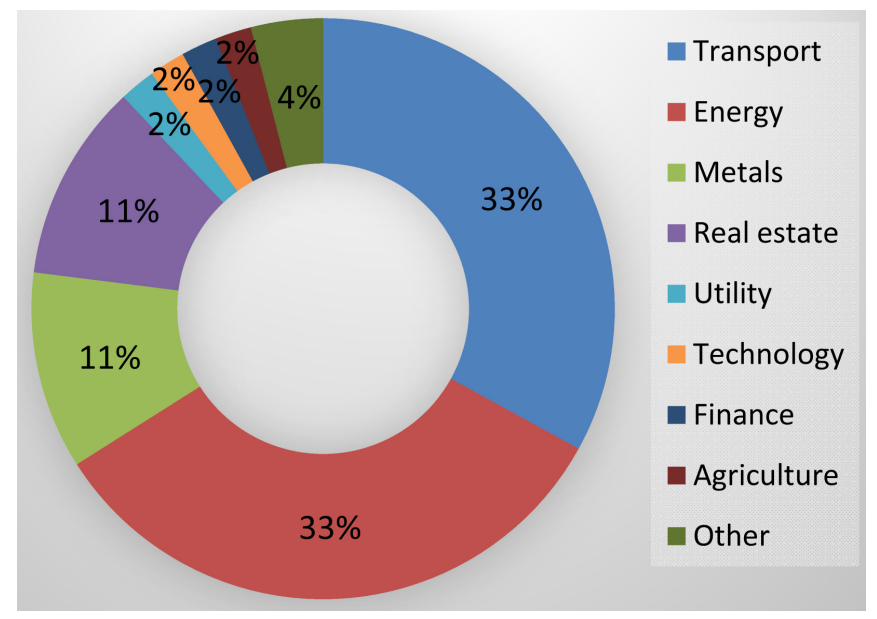

Figure 2. Chinese investment by Sectorial distribution in Africa 2018. Source: Author's elaboration from Chinese Investment Tracker AEI.

industry and manufacturing development, fostered technology transfer, and created jobs. "China investment plan" is more aimed at helping African countries achieve independent growth and development.

Electronic commerce is also an essential means of strengthening trade and investment facilitation in Africa. Thus, under market principles, China encourages its companies to explore "Internet+" cooperation with Africa to share the benefits of information technology and the big data economy. In 2018, the first China-Africa cross-border e-commerce platform, the China-Africa Network, was officially launched in Beijing to promote trade, investment, and collaboration among China and African countries, and even the world (Li, Huang, \& Lv, 2018).

Likewise, good quality and cheap Chinese products have also entered the homes of Africans through online sales. It is also worth mentioning the example of Alibaba International Station, whose volume of transactions in Africa has increased by $188 \%, 389.9 \%$, and $62 \%$ in the last three years. Africa now has 330 million Internet users, and $20 \%$ of them have an online shopping experience. The e-commerce market is multiplying and has excellent potential.

China still plans to promote Africa's agricultural modernization, industrialization, infrastructure construction of energy, transport.

\section{Comparative Analysis of U.S, U.E and China Strategies in Africa}

Comparing the strategies of the United States and other Western countries in Africa to those of China helps us comprehend the problems at stake in the Africa-China relationship. Since the entrance of the slave trade, colonialism and independence have all occurred. Western countries have been the dominant force. The effect of the West is noticeable in the politics, religion, economies, technology, and languages of Africans, to mention but a few. This influence has made Africans look towards the West as a reference and model for the economic sys- 
tem. It is not limited to African but is more prevalent there than in other parts of the world. This reference model mentality makes African countries look to the West for answers to most of their developmental and, at times, social issues. For a long time, the West has taken this for granted. It considers Africa an acquired area of influence, and Africans are weak and need guidance from their substantial power.

It is flagrant in the type of treatment received by many African nations from Western-dominated financial institutions. Aid, grants, loans, and contracts from the West sometimes come with restrictions that deny African countries their right to self-determination. A good example is the effort to privatize state companies and the West's imposition of structural adjustment programs on most of Africa's impoverished nations as first debt relief requirements. Moyo (2010) captures the futility of aid and loan programs when she states that: Aid has traditionally been tied in three ways by donors, for starters are linked frequently to procurement. Accepting nations must spend aid on specific products and services produced by the donor countries or a group of countries designated by them. It also applies to employees: Even if suitable individuals are available in the developing nation, funders recruit their countrymen. Second, the donor might reserve the right to choose which industry or initiative to assist with their help. Third, aid is given only to countries that agree to a set of economic and political policies (Nnajiofor, 2019). Moyo (2010) explained how exploited donor countries' aid reduced civil services, privatized national industries, and removed trade barriers.

On the other hand, the Chinese have consistently insisted on neutrality and non-obstruction in the domestic government issues of the nations in which they operate is also a requirement. It makes the Chinese option more appealing to the African nation since there is a sense of mutual respect and win-win cooperation that makes interactions easier. The Chinese government's efforts, mainly those carried out under the auspices of the Forum on China-Africa Cooperation (FOCAC), contribute to this sense of respect and equality (win-win) and seriousness for Africans (Nijs, 2013; Soumare et al., 2016).

Otherwise, as per Nnajiofor (2019), the main goal of Westerners that first ventured into Africa was doing business. Most of the nations of Africa that Westerners colonized had their treasures and fortune plundered. The theft is still going on in Africa's oil and mineral-rich countries. Western businesses organized and carried out it in Nigerian mines, the Democratic Republic of Congo's uranium reserves, Niger's cobalt and nickel fields, and Madagascar's forest.

In a symbolic sense, it's worth noting that the first major transaction between the Chinese and African governments resulted in completing one of Africa's most complex projects. The Chinese carried out the project, although they were not yet rich at the time.

The development of China's economy over the previous four decades has led many observers to overlook that it is still an emerging economy. This reality, however, does not prevent China from investing billions in Africa and other 
countries globally. A substantial part of these investments in Africa channel to infrastructure projects, which most observers agree are wanting in Africa. According to Mayaki (2019), only approximately $38 \%$ of Africa's population has access to electricity, internet penetration is less than $10 \%$, and only about a quarter of the continent's road network is paved. According to studies, inadequate road, rail, and port infrastructure raise products' costs between African nations by $30 \%$ to $40 \%$, limiting private sectors development and FDI flow.

China finished $\$ 40.38$ billion worth of infrastructure projects in Africa in 2012, and it has continued to do so in several African countries since then. Western doesn't seem much interested to invest in this sector.

The Chinese strategy to the infrastructure challenge, on the other hand, has been relatively best compared to the West. The Chinese substantially invest in African infrastructure and effectively complete projects at significantly reduced prices and on time or ahead of schedule (Ye, 2010). This strategy has shown to be more successful in creating Africa's much-needed infrastructure. In the World Bank study, Foster et al. (2009) observed that: Given Africa's massive infrastructure deficit, the emergence of China and other non-OECD entities as key funders appears to be a promising trend. Emerging financiers' assistance is unparalleled in terms of scope and concentration on large-scale infrastructure projects. In terms of loans and aids, Western is the best for this sector as they are old partners, and they familiarise these areas. Borrowers and financiers alike will have to learn new actors and modalities due to the new actors and modalities. The fundamental issue for African governments will be to figure out how to get the most out of all external infrastructure financing options, particularly those from developing lenders. Some African analysts have also noticed the significance of Chinese FDI and the seriousness and speed with which their infrastructure projects in Africa are being implemented (Kobo, 2013; Gold and Devadason, 2018; Yusuf et al., 2021).

\subsection{Potential Trade and Investment Advantage between China-Africa and Western-Africa}

China has an extensive investment portfolio in Africa. Chinese FDI reaches nearly all African nations, which exceeds some of the traditional African partners (see Table 1). Otherwise, the western countries also still have a significant role in most of the activity sector in Africa as an old partner. However, this part investigates the advantages of China-Africa, western-Africa investment, and trade.

\section{E.U.-Africa}

Investment and trade partnership with Africa-UE has existed since the colonization and continues. The establishment of the Africa-EU Cooperation Agreement and the first-ever meeting between the E.U. 27 members and Africa's 54 states in 2007 appears to have signaled a new beginning in the relationship between the two continents. Indeed, the E.U. has worked successfully over the last decade to shift to a form of cooperation founded on reciprocal trade. The 
Table 1. Stock of FDI in Africa from various economies U.E, U.S. and China (billion dollar).

\begin{tabular}{|c|c|c|c|c|c|c|}
\hline Countries & 2013 & 2014 & 2015 & 2016 & 2017 & 2018 \\
\hline U.E & 303.00 & 346.86 & 402.54 & 336.79 & 314.93 & 331.11 \\
\hline Netherlands & 114.05 & 129.70 & 168.81 & 119.29 & 117.83 & 136.20 \\
\hline France & 54.81 & 58.82 & 67.87 & 68.21 & 61.30 & 55.11 \\
\hline China & 27.82 & 34.37 & 36.87 & 42.36 & 46.01 & 48.98 \\
\hline United State & 52.54 & 67.66 & 56.85 & 58.36 & 49.90 & 48.00 \\
\hline United Kingdom & 52.01 & 64.88 & 63.01 & 62.68 & 45.85 & 46.14 \\
\hline Italy & 16.76 & 18.46 & 23.41 & 25.49 & 27.73 & 30.59 \\
\hline Germany & 9.62 & 10.53 & 9.75 & 11.48 & 11.41 & 14.98 \\
\hline Luxembourg & 24.23 & 26.81 & 29.68 & 11.86 & 11.42 & 11.08 \\
\hline Cyprus & 6.46 & 8.97 & 10.25 & 10.13 & 10.16 & 10.27 \\
\hline Japan & n.a & 9.82 & 9.73 & 11.27 & 8.26 & 8.83 \\
\hline Portugal & 8.27 & 10.61 & 10.40 & 8.97 & 10.26 & 8.57 \\
\hline Spain & 6.15 & 6.44 & 6.71 & 6.13 & 6.44 & 6.32 \\
\hline Sweden & 3.20 & 3.80 & 4.58 & 4.89 & 4.50 & 4.71 \\
\hline Denmark & 2.50 & 2.26 & 2.12 & 2.32 & 1.96 & 2.28 \\
\hline Belgium & 1.98 & 2.03 & 2.70 & 2.37 & 2.69 & 1.90 \\
\hline Malta & n.a. & n.a. & n.a. & 1.08 & 1.09 & 1.09 \\
\hline Poland & 0.20 & 0.19 & 0.25 & 0.32 & 0.31 & 0.23 \\
\hline Greece & 0.88 & 0.80 & 0.57 & 0.11 & 0.30 & 0.36 \\
\hline Croatia & 0.43 & 0.36 & 0.24 & 0.20 & 0.19 & 0.13 \\
\hline Slovenia & 0.20 & 0.22 & 0.22 & 0.12 & 0.11 & 0.02 \\
\hline Estonia & 0.01 & 0.01 & 0.01 & 0.01 & 0.02 & 0.04 \\
\hline Bulgaria & 0.00 & 0.01 & 0.01 & 0.01 & 0.01 & 0.01 \\
\hline Romania & 0.01 & 0.01 & 0.01 & 0.00 & 0.01 & 0,01 \\
\hline Hungary & 0.01 & 0.01 & 0.06 & 0,01 & 0,01 & 0.00 \\
\hline Latvia & 0.00 & 0.00 & 0.00 & 0.00 & 0.00 & 0.00 \\
\hline Lithuania & 0.00 & 0.00 & 0.00 & 0.00 & 0.00 & 0.00 \\
\hline Ireland & 0.14 & 0.40 & 0.43 & n.a. & -0.23 & -49.98 \\
\hline Czechia & n.a & n.a & 0.10 & n.a. & n.a. & 0.12 \\
\hline Austria & n.a. & n.a. & n.a. & n.a. & n.a. & n.a. \\
\hline Slovakia & 0.01 & 0.01 & 0.01 & n.a. & n.a. & n.a. \\
\hline
\end{tabular}

Source: Author's elaboration from Eurostat/MOFCOM/. Notes: The value 0.00 indicates the amount less than 0.01, and n.a. indicates unavailable data. Exchange rate: 1 Euro = $\$ 1.19$. FDI stock for the U.S in 2018 was taken from UNCTAD. 
fifth EU-Africa Summit was held in Africa in 2017 amid $\$ 300$ billion in bilateral trade. In connection with the meeting, the European Union pledged to invest more than $\$ 54$ billion in "sustainable" projects in Africa by 2020 .

The European Union expands its economic footprint in Africa by negotiating and signing Economic Partnership Agreements (EPAs) with 40 African governments in Sub-Saharan Africa. Over the next two decades, the EPAs will liberalize around $80 \%$ of imports, giving European firms privileged access to markets throughout the region. A comprehensive E.U. trade policy and a private sector with deep links to local needs pave the way for European businesses to continue developing and exert influence in the African market. Furthermore, because most African Union members have signed the Continental Free Trade Agreement (CAFTA), the E.U. is in a good position to impart experiences acquired during decades of regional economic integration.

\section{US-Africa}

Since 2000, the African Growth and Opportunity Act (AGOA), a non-reciprocal trade deal that provides duty-free access to the United States for roughly 6400 products, has served as the foundation for economic connections between the United States and Africa. AGOA's influence has mixed because its goal was to increase Africa's export markets rather than establish two-way trade and investment connections. AGOA assisted in integrating business and investment into US-Africa policy debates, leading more than a million employees on the continent, both directly and indirectly. Only around 300 of the permitted product lines are employed. A few countries have exploited AGOA to enhance non-oil exports to the United States, including South Africa, Lesotho, Kenya, Mauritius, Ethiopia, and Madagascar. U.S State Department launched "Prosper Africa" to give further investment possibilities for African businesses and growth.

\section{China-Africa}

China-Africa cooperation in trade and investment facilitation has been robust over the last ten years, yielding several spectacular outcomes. It has effectively promoted China's economic and trade exchanges with the African nation, boosted economic growth in Africa, and brought tangible benefits to the people of Africa 2017.

In 2017, McKinsey an international consulting firm, Chinese companies have contributed to the growth of the African economy by bringing investments, managerial expertise, and innovations to the continent. Eighty-nine percent of employees in over 1000 Chinese enterprises examined are African; in the previous three years, around 48 percent of Chinese corporations have offered new goods or services to the African continent, and 36 percent have introduced new technology. Chinese partners have completed infrastructure projects with lower cost finance and improved efficiency, making a significant contribution to local development; with the development of e-commerce networks, mobile payment is also becoming more and more popular in Africa. There are around 338 million mobile payment accounts in sub-Saharan Africa, and many sites allow payments 
via Alipay and WeChat (Li, Huang, \& Lv, 2018).

\subsection{Comparison between U.S., E.U., and Chinese FDI Stocks in Africa}

Three countries are giant investors in Africa as well as worldwide, U.S, U.E., and China. In 2018, the Netherlands was recognized globally as a tax haven. Thus these FDI are among the top in Africa following by France who continues to have the highest stock of FDI, amounting to $\$ 54.74$ billion. China, which ranks second with a stock down by just $\$ 6.13$ billion ( $\$ 48.96$ billion), might threaten this supremacy soon. According to Eurostat 2018, the United States was third in 2017 but surpassed by China in 2018, ahead of the United Kingdom ( $\$ 2.82$ million less than China), Italy ( $\$ 18.57$ million less than China), and Germany (\$37.88 million less than China).

Western countries have a total investment stock in Africa of more than ten billion dollars compared to China. Table 1 shows that China's growth is quite noticeable. On the other hand, traditional partners cannot claim that they no longer invest in Africa since Western investors must spend some of their profits while simultaneously replacing ancient capital to maintain a certain level of investment stock. Indeed, we are seeing not the abandonment of established allies but the acquisition of a new and powerful partner-China. So, China is raised in trade and investment in Africa and is still planning to rank on the top.

\section{Chinese vs. US FDI in Africa}

In 2013, commerce between China and Africa totaled over $\$ 200$ billion, with Chinese electronics and textiles pouring into African countries and African natural resources transported to China. Surprisingly, Chinese-African commerce was more than double that of the United States and Africa (Figure 3).

China might learn from the United States and spend more in critical social areas as a new African partner. Health and education should be prioritized and serve high-profile capital expenditure and construction projects. While many of these infrastructure projects help Africans, China and Chinese companies must invest in environmental sustainability and acknowledge and accept external costs such as environmental devastation.

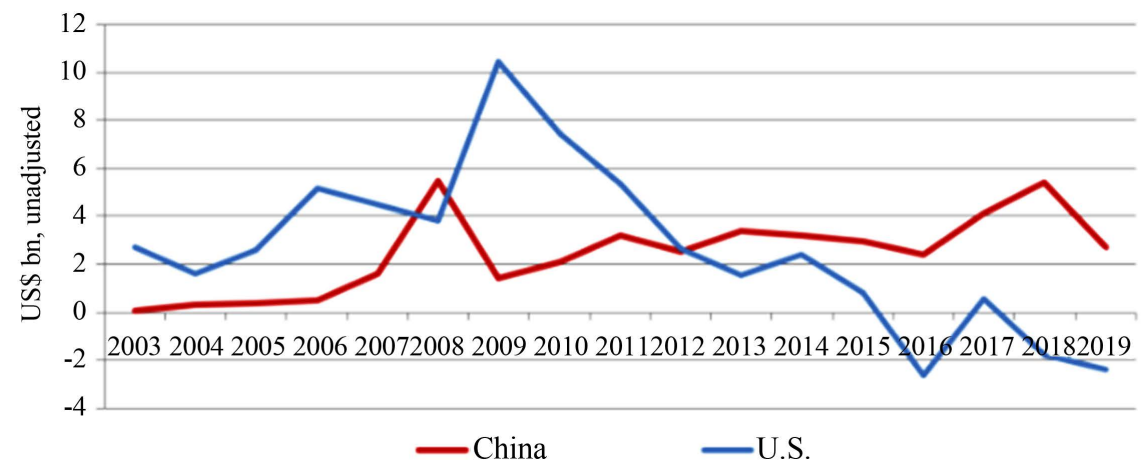

Figure 3. Chinese vs. US FDI to Africa, flow. Source: the statistical bulletin of China's outward Foreign Direct Investment, U.S bureau of economic analysis/Johns Hopkins. 
Since 2013, Chinese FDI into Africa has surpassed that of the United States. As seen in the graph below, although U.S FDI flows declining since 2010. In 2019, a new convention for prospering Africa established U.S to maintain the excellent relationship between U.S. and Africa.

Chinese vs. E.U. investment

China's expanding and deeper presence in Africa has received a lot of attention. Between 2000 and 2017, Commercial loans from China to African governments and state-owned enterprises totaled $\$ 154.7$ billion. China is currently the region's largest bilateral borrower, accounting for $20 \%$ of Africa's foreign public debt, according to the China-Africa Research Initiative (CARI). But the stock of Chinese FDI in Africa is still less than some European countries with colonial past in the continent, such as the Netherlands, France, accounting for only $5 \%$ of global FDI, it is catching up. Between 2016 and 2018, its total FDI inflows to African countries were $13 \%$ greater than most of the European Union's total (Table 1) except the Netherland and France. For the foreseeable future, Chinese investment might be a key component of Africa's finance landscape.

\subsection{The Main Investing Countries of China and Western Countries in Africa}

Most of the old investors (western) in Africa are overwhelmed by Chinese investments (Table 2). China's irruption into the African market has changed the game of development in Africa; it increased the demand and multiplied the partners that Africans could turn. Therefore, Africa's significant relationship of growth and development could have been no longer the same as the one we could know when the relationship remained very bilateral with European countries and somewhat with the United States (Strauss-Kahn, 2019).

These 25 countries benefitted from 96\% of European FDI in Africa and 89\% of Chinese FDI in Africa. On the other hand, European investment focuses on fewer African countries than Chinese investment does.

In 2017, three countries came to the top of the list of investor countries, with the most first, second, and third places: China (with twenty places), France (with nineteen places), and the United States (with thirteen places). The number of recipient countries further demonstrates China's advantage. It is top on the list of investor nations (eleven), followed by France (eight) and the United States (three). Even though China is gaining political clout in Africa, France and the United States remain the most prominent economic investors, according to Pairault (2020).

\subsection{Comparables Situation}

The Chinese aren't only putting money into Africa. Their investments are seen in the economy of various nations and areas throughout the world. Asian countries are the initial receivers of Chinese FDI. In addition, China has made significant investments in the established economies of North America and Europe. 
Table 2. Main investor countries and Africa Recipient countries.

\begin{tabular}{|c|c|c|c|c|c|c|}
\hline \multirow{2}{*}{$\begin{array}{l}\text { Recipient } \\
\text { countries }\end{array}$} & \multicolumn{6}{|c|}{ investors countries by size of their FDI stock 2017} \\
\hline & $1^{\text {st }}$ & $2^{\text {nd }}$ & $3^{\text {rd }}$ & $4^{\text {th }}$ & $5^{\text {th }}$ & $6^{\text {th }}$ \\
\hline Algeria & Italy & USA & France & China & Germany & UK \\
\hline Angola & France & China & USA & Italy & Germany & UK \\
\hline Congo & France & China & USA & Italy & UK & Germany \\
\hline Congo DCR & China & France & Germany & USA & Italy & UK \\
\hline Ivory Coast & France & China & Italy & Germany & UK & USA \\
\hline Egypt & USA & Italy & France & Germany & China & UK \\
\hline Ethiopia & China & Germany & USA & France & UK & Italy \\
\hline Ghana & France & USA & China & UK & Germany & Italy \\
\hline Guinea & China & Italy & France & USA & UK & Germany \\
\hline Kenya & China & France & UK & USA & Germany & Italy \\
\hline Madagascar & China & Italy & Germany & UK & France & USA \\
\hline Mauritius & USA & UK & France & China & Germany & Italy \\
\hline Morocco & France & Italy & Germany & USA & China & UK \\
\hline Mozambique & China & USA & UK & Italy & Germany & France \\
\hline Namibia & China & Germany & Italy & UK & France & USA \\
\hline Niger & France & China & Italy & UK & Germany & USA \\
\hline Nigeria & France & USA & China & Italy & Germany & UK \\
\hline Senegal & France & China & USA & Germany & Italy & UK \\
\hline South Africa & UK & China & USA & Germany & France & Italy \\
\hline Sudan & China & Italy & France & USA & Germany & UK \\
\hline Tanzania & USA & China & France & UK & Germany & Italy \\
\hline Tunisia & Italy & France & USA & Germany & China & UK \\
\hline Uganda & China & UK & France & Germany & Italy & France \\
\hline Zambia & China & UK & U. K & USA & Italy & Germany \\
\hline Zimbabwe & China & France & UK & USA & Italy & Germany \\
\hline
\end{tabular}

Source: Author's elaboration from Eurostat/MOFCOM/.

The Chinese are increasingly investing in the European economy. Although the examples of Greece and Spain spring to mind first, Chinese investment is not restricted to those two nations. Chinese FDI touches many European countries and has been on a rapid increase in the last decade. In 2013, France signed a commercial agreement of $\$ 22.8$ billion with the Chinese in nuclear energy, air transportation, and telecommunications. According to the French Foreign Ministry, "Chinese investment in France has increased significantly in recent years" 
(In FDI stock, \$7.14 billion). In 2019, 700 Chinese and Hong Kong firms established subsidiaries in France, employing 45,000 people. The latest E.U. legislative measures to check foreign investments in strategic sectors are more political than economic. The Italian government signed up for the Belt and Road Initiative despite criticisms shows.

China's commercial connections with Germany are critical in Germany's recent economic solid development compared to other European nations. They also underpin German support for China in European discussions.

China's investments in other parts of the globe are rising in a globalized world economy. Chinese firms invest billions of dollars in the United States, Canada, Latin America, and Australia.

\subsection{The Belt and Road Initiative}

The Silk Road Economic Belt, which links Europe by land and Central Asia, and the 21st Century Maritime Silk, which connects Africa, South Asia, Southeast Asia, and eventually Europe, are part of the BRI.

One hundred twenty-five nations and international organizations have signed 123 agreements under the aegis of the BRI. The African Union is involved, as are 37 African countries. Trade between China and BRI nations increased by more than $\$ 5$ trillion in the five years preceding June 2018. Through the BRI, Chinese FDI totaled US $\$ 70$ billion, with over US\$500 billion in Engineering, Procurement, and Construction (EPC) contracts inked. Over 82 economic cooperation zones have been formed, employing 244,000 people in host nations (Marais \& Labuschagne, 2019).

East Africa's coastline area has played a critical role in expanding China's zone of commercial influence by connecting it to the so-called Maritime Silk Route. According to the African Construction Trends study, Chinese bankers and builders are focusing their efforts in Eastern Africa, especially in the shipping, transportation, and port sectors. Ethiopia's Addis Ababa-Djibouti railway and Kenya's Nairobi-Mombasa railway are both significant East African projects. Tanzania's Bagamoyo port, which is now under construction, will be East Africa's most prominent.

In June 2017, the 3.2 billion dollar Nairobi-Mombasa railway opened to replace the 4000 cars that travel the route every day. Many vehicles from Kenya and neighboring African nations such as Burundi and Rwanda utilize the road regularly (Githaiga et al., 2019). As part of a larger regional integration goal, China invests in raising the ambition of Africa railway projects. The railway will be extended south to Kigali, Rwanda, and Uganda's capital, Kampala. As per the World Bank, a $1 \%$ decrease in trade costs results in a 1.3 percent rise in bilateral trade between countries participating in BRI projects. Improvements to railroad networks and capacity and other cross-border transportation infrastructure may result in more intra-African transactions, more significant investment, knowledge transfer, and better growth in African countries (Sylodium, 2020). 


\section{Conclusion and Recommendation}

\subsection{Conclusion}

A vital relationship between the U.S, U.A., and China has occurred globally regarding investment and trade in Africa. China and western countries are Africa's most significant investors and partners and are more attracted by African raw materials.

Despite their different strategies on investment and trade in Africa, their business contributes to the general growth and development of host economies. It has served as a means of employment and boosted growth and development opportunities for investors and the host continent. It is positive for the African economy because it reduces unemployment and the general poverty rate in the continent.

Through the various positive contributions of their investments in Africa, the investors have seen Africa's potential. It has created a marriage of opportunities for both actors. It is a dependent relationship between the investors and Africa.

In the case of China, Africa is offering oil and the raw materials that's she has in abundance and getting in return infrastructures that she needs. I submit that is a win-win situation, and the famous agreement Belt Road initiative offers African countries a seemingly colossal opportunity.

Aside from western countries, old investors in Africa, the U.S, as the largest world economy, mainly invests in Sub-Saharan countries. U.S remains a critical player, especially on the AGOA initiative's ineffectiveness, which needs new ideas and strategies for many key issues. We conclude that the situation is the investor's benefit more than the host country.

The difference of U.E. strategies in Africa is that U.E is not only the old investors but also the old African trade partner. Its presence in Africa was before and after the independence of African countries. As a colonizer, U.E has established its economic system in the continent; it has made African countries look towards the West as a reference and model for the economic system and give advantage to the U.E.

The community's comparative advantage between China and western trade and investment in Africa is high. Each country targets the fields that they see benefits in terms of investment and compete to conquer the top market in business.

This investment makes Africa more attractive to the world by substantial investment that will attract other foreign investors. As China's global power position rises, what happens in Africa may become a matter of greater interest.

\subsection{Recommendation}

Nowadays, China's investment is the most popular and robust in Africa, surpassing the U.S and U.A, the principal partner of Africa. The problem of Chinese commercial loans and debt acquired by African countries is expected to become a public policy concern as China builds the Belt and Road Initiative, the 
world's largest infrastructure project. Because of its assistance for Africa's desperately needed infrastructural initiatives, China should consider switching to a mixed financing approach that relies on both Chinese and Western financial sources to mitigate the negative consequences of these loans.

China has had a long-standing relationship with Africa since the 1960s. However, only in the last few decades has the relationship between FDI, trade, and aid has been increased to a new, higher level. Chinese investment is still, however, less than the percentage of the total investment from the U.E received by Africa. So, to strengthen China-Africa collaboration, China should establish strong friendship connections, which they already have, and then the rest will fall into place. When there are specific Chinese projects, firms in the nations should hire more African nationals because the project is supposed to create jobs in the host countries.

\section{Conflicts of Interest}

The author declares no conflicts of interest regarding the publication of this paper.

\section{References}

Ajakaiye, O. (2006). China and Africa-Opportunities and Challenges. https://www.africaportal.org/publications/china-and-africa-opportunities-and-challeng es/

Balassa, B. (1978). Exports and Economic Growth: Further Evidence. Journal of Development Economics, 5, 181-189. https://doi.org/10.1016/0304-3878(78)90006-8

Dunning, J. H. (2000). The Eclectic Paradigm as an Envelope for Economic and Business Theories of MNE Activity. International Business Review, 9, 163-190. https://doi.org/10.1016/S0969-5931(99)00035-9

Eisenman, J. (2012). China-Africa Trade Patterns: Causes and Consequences. Journal of Contemporary China, 21, 793-810. https://doi.org/10.1080/10670564.2012.684964

Foster, V., Butterfield, W., Chen, C., \& Pushak, N. (2009). Building Bridges: China's Growing Role as Infrastructure Financier for Sub-Saharan Africa. The World Bank. https://doi.org/10.1596/978-0-8213-7554-9

Githaiga, N. M., Burimaso, A., Wang, B., \& Ahmed, S. M. (2019). The Belt and Road in Initiative: Opportunities and Risks for Africa's Connectivity. China Quarterly of International Strategic Studies, 5, 117-141. https://doi.org/10.1142/S2377740019500064

Gold, K. L., \& Devadason, E. S. (2018). The Engagement of China in Nigeria's Oil Sector: Is the Transformation Positive? Contemporary Chinese Political Economy and Strategic Relations: An International Journal, 4, 1025-1060. https://www.researchgate.net/publication/329737339

Grossman, G. M., \& Helpman, E. (1991). Quality Ladders in the Theory of Growth. The Review of Economic Studies, 58, 43-61. https://doi.org/10.2307/2298044

Heckscher, E. F., \& Ohlin, B. G. (1991). Heckscher-Ohlin Trade Theory. MIT Press.

Helpman, E., Melitz, M. J., \& Yeaple, S. R. (2004). Export versus FDI with Heterogeneous Firms. American Economic Review, 94, 300-316.

https://doi.org/10.1257/000282804322970814 
Kobo, O. M. (2013). A New World Order? Africa and China. Xinhua Net.

Krugman, P. R., Obstfeld, M., \& Melitz, M. J. (2012). International Economics: Theory and Policy (9th ed.). Addison-Wesley.

Li, Y. Q., Huang, P. Z., \& Lv, Q. Y. (2018). China-Africa Trade and Investment Cooperation Stronger than Ever. French.People.cn.

http://french.peopledaily.com.cn/Economie/n3/2018/0830/c31355-9495665.html

Marais, H., \& Labuschagne, J. P. (2019). If You Want to Prosper, Consider Building Roads China's Role in African Infrastructure and Capital Projects. Deloitte.

Mayaki, I. (2019). Why Infrastructure Development in Africa Matters.

https://www.un.org/africarenewal/web-features/why-infrastructure-development-africa -matters

Miao, M., Jiang, Y. S., \& Borojo, D. G. (2020). The Impacts of China-Africa Economic Relation on Factor Productivity of African Countries. Economies, 8, Article No. 47. https://doi.org/10.3390/economies8020047

Moyo, D. (2010). Dead Aid: Why Aid Is Not Working and How There Is a Better Way for Africa. Ethics \& International Affairs, 23, 219. https://doi.org/10.1111/j.1747-7093.2009.00211_2.x

Nijs, A. (2013). In the Economic Consequences of China Africa Relations: Debunking Myths in the Debate. AGDI Working Paper WP/13/020, 10-11.

Nnajiofor, P. (2019). Chinese and Western Investments in Africa: A Comparative Analysis. Hal-02940907. https://hal.univ-lorraine.fr/hal-02940907

Pairault, T. (2020). Guest Post-Investment in Africa: China vs. "Traditional Partners". China in Africa: The Real Story.

http://www.chinaafricarealstory.com/2020/07/guest-post-investment-in-africa-china.ht $\underline{\mathrm{ml}}$

Ricardo, D. (1891). Principles of Political Economy and Taxation. G. Bell \& Sons.

Ricardo, D. (1955). The Works and Correspondence of David Ricardo: Volume 10, Biographical Miscellany. Cambridge University Press.

Silajdzic, S., \& Mehic, E. (2018). Trade Openness and Economic Growth: Empirical Evidence from Transition Economies. Intech Open.

https://doi.org/10.5772/intechopen.75812

Soumare, I., Gohou, G., \& Kouadio, H. (2016). Comparative Study of FDI Characteristics from China to Africa versus Developed Countries. Transnational Corporations Review, 8, 165-177. https://doi.org/10.1080/19186444.2016.1233715

Strauss-Kahn, D. (2019). Africa on the Cusp of a Crucial Decade. https://www.theafricareport.com/21723/africa-on-the-cusp-of-a-crucial-decad

Sylodium (2020). What the BRI Could Mean for Africa.

https://www.sylodium.com/en/news/what-the-bri-could-mean-for-africa/2588

UNCTAD and UNDP (2007). Asian Foreign Direct Investment in Africa: Towards a New Era of Cooperation among Developing Countries. UNCTAD Current Studies on FDI and Development No. 3. United Nations University Press.

Wang, J.-Y. (2007). What Drives China's Growing Role in Africa? IMF Working Paper WP/07/211, International Monetary Fund. https://doi.org/10.5089/9781451867756.001

Xinhua (2021). China's Machinery Industry Reports Double-Digit Growth in Jan.-Aug. http://www.news.cn/english/2021-10/10/c_1310235751.htm

Xu, W. (2008). Sino-African Relations: New Transformations and Challenges. In D.-G. Gerrero, \& F. Manji (Eds.), China's New Role in Africa and the South, Fahamu and 
Focus on the Global South (pp. 12-20), Cape Town and Bangkok.

Ye, X. (2010). A Path to Mutual Prosperity? The Trade and Investment between China and Africa. World Bank.

https://archive.uneca.org/sites/default/files/uploaded-documents/AEC/2010/Papers/ses sion-ii-1-2_1_a-path-to-mutral-prosperity_the-trade-and-investment-between-china-a nd-africa.pdf

Yusuf, H. A., Afolabi, L. O., Shittu, W. O., Gold, K. L., \& Muhammad, M. (2021). Institutional Quality and Trade Flow. Empirical Evidence from Malaysia and Other OIC Member Countries in Africa. Insight on Africa, 13, 177-191.

https://doi.org/10.1177/0975087820987174 